\title{
Stable C and N Isotope Composition of European Anchovy, Engraulis encrasicolus, from the Marmara Sea and the Black Sea
}

\author{
Tanju Mutlu, ${ }^{1, a}$,* \\ ${ }^{I}$ Department of Environmental Protection and Control, Recep Tayyip Erdogan University, 53100 Rize, Turkey \\ *Corresponding author

\begin{tabular}{l|l}
\hline A R T I C L E I N F O & A B S T R A C T \\
\hline Research Article & $\begin{array}{l}\text { The aim of this study is to determine the stable isotope ratios of anchovy caught in the Black Sea } \\
\text { and Marmara Sea. Stable carbon and nitrogen isotope ratios }\left(\delta^{13} \mathrm{C}, \delta^{15} \mathrm{~N}\right) \text { of European anchovy } \\
\text { (Engraulis encrasicolus) were estimated at four sampling sites (İgneada, İstanbul, Trabzon and } \\
\text { Hopa) in the Black Sea and Marmara Sea (Turkey). } \delta^{13} \mathrm{C} \text { and } \delta^{15} \mathrm{~N} \text { values of European anchovy } \\
\text { Received : } 27 / 01 / 2021\end{array}$ \\
Accepted : $27 / 02 / 2021$ & $\begin{array}{l}6.21 \text { in muscle tissue of European anchovy, respectively. İğneada station had more depleted } \delta^{13} \mathrm{C} \\
\text { values and more enriched } \delta^{15} \mathrm{~N} \text { values than other stations. This difference might be due to the } \\
\text { terrestrial input and agricultural activities in this region. }\end{array}$
\end{tabular}

Keywords:

Stable isotopes

Engraulis encrasicolus

Fish

Carbon

Nitrogen

tanju.mutlu@erdogan.edu.tr (iD)htps://orcid.org/0000-0001-6514-6914|

(c) (1) (9) This work is licensed under Creative Commons Attribution 4.0 International License

\section{Introduction}

Stable isotope analysis (SIA) can be used as ecological tracers of the diet (Peterson and Fry, 1987; Abend and Smith, 1997; Dempson et al., 2010; Kloskowski et al., 2019) and can provide information about dietary sources (Lesutiene et al., 2018). While isotope ratios of oxygen, hydrogen, sulphur, and strontium help ecological studies, stable isotopes of carbon and nitrogen are the most widely used one (Bodey et al., 2011). The stable nitrogen isotope ratio $\left(\delta^{15} \mathrm{~N}\right)$ have been used to define trophic levels of organisms and to estimate of the source of nitrogen (Koszelnik et al., 2008; Duarte et al., 2018; Noh et al., 2019), while the stable carbon isotope ratio $\left(\delta^{13} \mathrm{C}\right)$ have been used to determine organic material sources and fluxes in biological systems (Fry and Sherr, 1984; Peterson and Fry, 1987; Owens, 1988; Einfalt et al., 2020). Stable isotope ratios of carbon $\left({ }^{13} \mathrm{C} /{ }^{12} \mathrm{C}\right)$ and nitrogen $\left({ }^{15} \mathrm{~N} /{ }^{14} \mathrm{~N}\right)$ differ between autotrophs, and these isotopic signs taken by consumers are reflected in their tissues, at whatever trophic level they occur (Fry, 1984; Peterson, 1999; Melville and Connolly, 2003). It is also known that the isotope composition of fish tissue provides information about the background, feeding, and movement of fish. While consumer's $\delta^{13} \mathrm{C}$ is enriched by $0.4 \%$ per trophic level, $\delta^{15} \mathrm{~N}$ is increased by 3-4 \%o per trophic level (Post, 2002; Davias et al., 2014).

The majority of aquaculture production in Turkey is obtained through catching and is supplied from a $79 \%$ portion of the marine area (Şahin et al., 2006). Most caught species of fish are European anchovy (Engraulis encrasicolus Linnaeus, 1758) in Turkey (TUIK, 2019). The European anchovy is a fast-growing and short-lived species that reaches its sexual maturity approximately at the first age with $9 \mathrm{~cm}$ length (Prodanov et al., 1997; Kideys et al., 1999; Samsun et al., 2004). It spawns in ten or more batches between May and September, and its mean individual fecundity was reported as 42000 number eggs (Polat and Ergün, 2008). European anchovy in the Black Sea is monitored as two subspecies. These are Engraulis encrasicolus ponticus (Black Sea anchovy) that can grow up to $18-20 \mathrm{~cm}$ and Engraulis encrasicolus maeticus (Azov anchovy) that can grow up to $15 \mathrm{~cm}$ (Erdoğan Sağlam and Sağlam, 2013). 
Stable isotope ratios of European anchovy (Engraulis encrasicolus) have been studied by many researchers (Kideys et al., 1999; Wan et al., 2010; Rumolo et al., 2018). But there has been no research on this subject in Turkey. The purpose of this study is the isotopic determination of geographical variations between European anchovy samples caught in the Marmara and the Black Sea. To that end, the $\mathrm{C}$ and $\mathrm{N}$ ratios in European anchovy were determined and compared with studies in different ecosystems.

\section{Material and Method}

\section{Sampling Area}

European anchovy samples were collected from four different locations in November, 2019. The sampling locations included: Trabzon (SC, $41^{\circ} 08^{\prime} 21.9^{\prime \prime} \mathrm{N}$, $\left.39^{\circ} 24^{\prime} 52.7^{\prime \prime E}\right)$, Hopa (SD, 41 $\left.{ }^{\circ} 24^{\prime} 51.1^{\prime \prime} \mathrm{N}, 41^{\circ} 24^{\prime} 29.8^{\prime \prime} \mathrm{E}\right)$ and İğneada (SA, 41 $\left.52^{\prime} 06.5^{\prime \prime} \mathrm{N}, 28^{\circ} 00^{\prime} 48.5^{\prime \prime} \mathrm{E}\right)$ in the Black Sea and İstanbul (SB, 41 $\left.09^{\prime} 26.0^{\prime \prime} \mathrm{N}, 29^{\circ} 03^{\prime} 22.4^{\prime \prime} \mathrm{E}\right)$ in the Marmara Sea (Figure 1). Samples were obtained from fishing vessels using a purse seiner in the Black Sea and the sea of Marmara. Eight fish samples collected from each station were brought to the laboratory in cold storage. All European anchovy samples were kept in a portable refrigerator and stored at $-25^{\circ} \mathrm{C}$ until further analysis.

\section{Stable Isotope Analysis}

White muscle tissue in fish is less variable than other tissues and is the ideal tissue in ecological studies (Pinnegar and Polunin, 1999). A white muscle portion close to the dorsal fin of the fish was removed and dried at $60^{\circ} \mathrm{C}$ for 48 hours (Buhan et al. 2018). The dried samples were ground to a fine powder $(<6 \mu \mathrm{m})$ using a mortar and pestle. To remove carbonate from the samples, it was acidified dropwise with $1 \mathrm{molL}^{-1} \mathrm{HCl}$ until no $\mathrm{CO}_{2}$ was released. The acidified samples were re-dried at $60^{\circ} \mathrm{C}$ without rinsing and pulverized again (Wang et al., 2015). For the measurement of stable $\mathrm{C}$ and $\mathrm{N}$ analysis rates, 0.15 $\mathrm{mg}$ of powdered samples were weighed and were placed in tin capsules. Stable isotope ratios were calculated using the equation below (1);

$$
\delta^{13} \mathrm{C} \text { or } \delta^{15} \mathrm{~N}=\left[\mathrm{R}_{\text {sample }} / \mathrm{R}_{\text {standard }}-1\right] \times 1000
$$

Where $\mathrm{R}={ }^{13} \mathrm{C} /{ }^{12} \mathrm{C}$ or ${ }^{15} \mathrm{~N} /{ }^{14} \mathrm{~N}$ ratio. PeeDee Belemnite (VPDB) was used as the standard for carbon, and atmospheric $\mathrm{N}_{2}$ was used for nitrogen (Fry, 2006). Stable isotope ratios of carbon and nitrogen were measured with a Thermo-Electron Flash EA 2000 elemental analyser (EA) coupled Isotope Ratio Mass Spectrometer (Thermo, Waltham, MA, USA).

$\mathrm{C} / \mathrm{N}$ ratios could be used to normalize $\delta^{13} \mathrm{C}$ because lipid content may cause deviations in stable isotope ratios (Post et al., 2007). Since most fish in the Black Sea has high lipid content (Banaru and Harmelin-Vivien, 2009), $\delta^{13} \mathrm{C}$ values have been rearranged according to the formula calculated by Post et al., (2007) to prevent deviation in stable isotope ratios (2):

$$
\delta^{13} \mathrm{C}_{\text {normalised }}=\delta^{13} \mathrm{C}_{\text {untreated }^{-3.32+0.99 \times C / N}}
$$

According to the results obtained, the effects of $\delta^{13} \mathrm{C}$ values and lipid concentration on $\delta^{13} \mathrm{C}$ are normalized.

\section{Statistical Analysis}

Stable isotope ratios of muscle tissue from different locations were statistically compared. All statistical analyses were performed using the platform SPSS 21.0 software. The Kolmogorov-Smirnov test was used in order to check the normality of all data. The non-parametric Kruskal-Wallis H-test was used to determine the differences between stations.

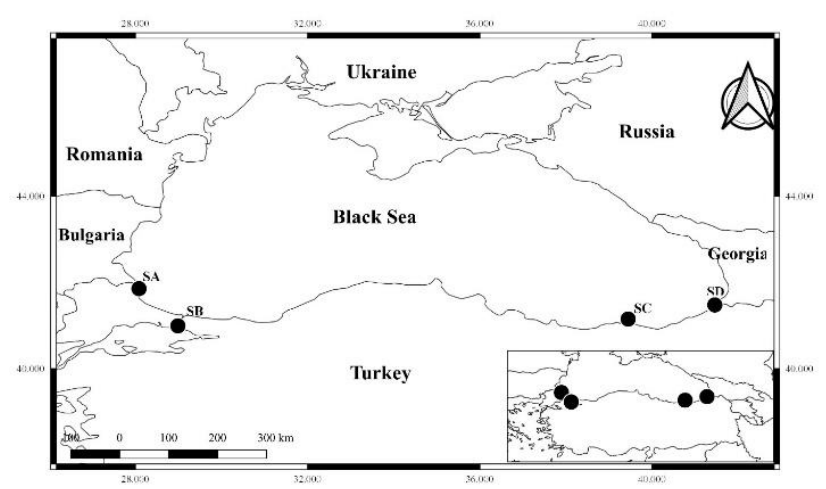

Figure 1. Sampling station of European anchovy in the Marmara and the Black Sea

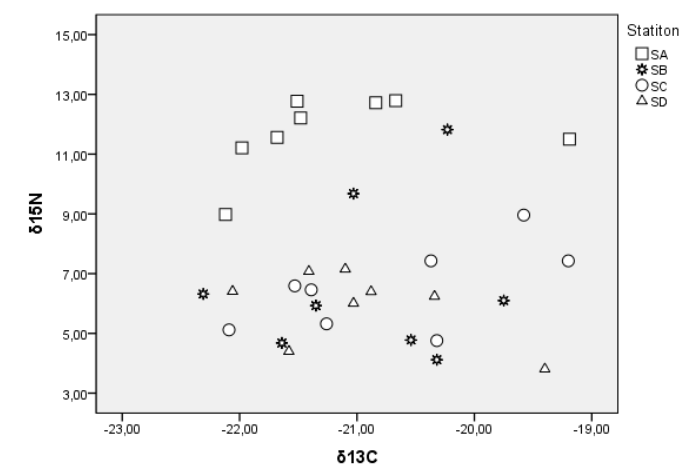

Figure 2. Carbon and nitrogen stable isotope biplots of European anchovy from SA (İğneada), SB (İstanbul), SC (Trabzon), and SD (Hopa)

\section{Result}

Total organic carbon (TOC \%), total nitrogen (TN \%), and stable isotope ratios of carbon $\left(\delta^{13} \mathrm{C}\right)$ and nitrogen $\left(\delta^{15} \mathrm{~N}\right)$ were evaluated in the muscle tissue of European anchovy caught the Marmara and Black Sea. The $\delta^{13} \mathrm{C}$ and $\delta^{15} \mathrm{~N}$ values of European anchovy showed significant differences in the location (Figure 2).

Findings show that $\delta^{13} \mathrm{C}$ and $\delta^{15} \mathrm{~N}$ values ranged from 22.31 to $-19.19 \%$ and from 3.81 to $12.79 \%$, respectively, while $\mathrm{C} / \mathrm{N}$ ratios ranged from 2.01 to 6.21 in muscle tissue of European anchovy. The $\delta^{13} \mathrm{C}$ and $\delta^{15} \mathrm{~N}$ signatures of fish varied from $-22.12 \%$ to $-19.19 \%$ o and from $8.98 \%$ o to $12.79 \%$ for SA, from $-22.31 \%$ to $-19.75 \%$ and from $4.12 \%$ o to $11.82 \%$ o for SB, from $-22.09 \%$ o to $-19.20 \%$ and from $4.76 \%$ to $8.96 \%$ o for $\mathrm{SC}$, and from $-22.06 \%$ to $19.40 \%$ and from $3.81 \%$ to $7.15 \%$ o for SD, respectively. 
Table 1. Stable isotope values (mean \pm SD) of anchovy in different area.

\begin{tabular}{|c|c|c|c|c|}
\hline Location & Species & $\bar{n}$ & $\delta^{13} \mathrm{C}(\%)$ & $\delta^{15} \mathrm{~N}(\%)$ \\
\hline Sagami Bay $^{1}$ & Engraulis japonicus & 84 & $-17.4 \pm 2.0$ & $11.2 \pm 2.0$ \\
\hline Kashima Nada ${ }^{1}$ & Engraulis japonicus & 4 & $-17.9 \pm 1.6$ & $10.1 \pm 1.4$ \\
\hline Suruga Bay ${ }^{1}$ & Engraulis japonicus & 5 & $-17.4 \pm 0.2$ & $11.0 \pm 0.2$ \\
\hline the Bay of Biscay ${ }^{2}$ & Engraulis encrasicolus & & $-18.4 \pm 0.4$ & $9.8 \pm 0.6$ \\
\hline Cabras Lagoon ${ }^{3}$ & Engraulis encrasicolus & & & $16.4 \pm 18.8$ \\
\hline Gironde estuary $^{4}$ & Engraulis encrasicolus & & & $9.1 \pm 0.6$ \\
\hline Mediterranean $\mathrm{Sea}^{5}$ & Engraulis encrasicolus & 171 & from -18.66 to -16.18 & $5.97-11.38$ \\
\hline İğneada ${ }^{6}$ & Engraulis encrasicolus & 8 & $-21.18 \pm 1.53$ & $11.72 \pm 1.27$ \\
\hline İstanbul ${ }^{6}$ & Engraulis encrasicolus & 8 & $-20.91 \pm 1.52$ & $6.68 \pm 2.69$ \\
\hline Trabzon $^{6}$ & Engraulis encrasicolus & 8 & $-20.72 \pm 1.01$ & $6.51 \pm 1.42$ \\
\hline Hopa $^{6}$ & Engraulis encrasicolus & 8 & $-20.98 \pm 0.82$ & $5.94 \pm 1.21$ \\
\hline
\end{tabular}

Mean isotopic values of sampled fish in Trabzon (SC) and in Hopa (SD) areas were similar both in $\delta^{15} \mathrm{~N}$ and $\delta^{13} \mathrm{C}$. In İstanbul (SB) area, mean $\delta^{15} \mathrm{~N}$ was similar to SC and SD values, while mean $\delta^{13} \mathrm{C}$ showed a higher value. In İğneada (SA) location, mean $\delta^{15} \mathrm{~N}$ was more enriched than all sites, while mean $\delta^{13} \mathrm{C}$ was more depleted than other sites (Figure 2). The $\mathrm{C} / \mathrm{N}$ signatures of fish varied from 4.07 to 2.71 for $\mathrm{SA}$, from 2.92 to 2.01 for $\mathrm{SB}$, from 6.21 to 3.10 for $\mathrm{SC}$, and from 3.74 to 2.98 for $\mathrm{SD}$, respectively. It was observed that the difference was statistically significant in SB and SD stations for $\delta^{13} \mathrm{C}$ values and only in the SA station for $\delta^{15} \mathrm{~N}$ values $(\mathrm{P}<0.05)$. In addition, $\mathrm{C} / \mathrm{N}$ values at $\mathrm{SC}$ and $\mathrm{SB}$ stations were found to be statistically significant $(\mathrm{P}<0.05)$.

\section{Discussion and Conclusions}

In this study, the isotopic changes of the European anchovy caught in the Black Sea and the Marmara Sea in different ecosystems were monitored. It is found that stable isotope signatures of carbon and nitrogen for anchovy were lower than the reported ones in previous studies (Table 1).

$\delta^{13} \mathrm{C}$ values ranged from -22.31 to $-19.19 \%$. The average $\delta^{13} \mathrm{C}$ value was $-20.94 \%$. The results were found to be more depleted than research in the literature (Miyachi et al., 2013; Chouvelon et al., 2014; Rumolo et al., 2016). Banaru and Harmelin-Vivien (2009) also determined $\delta^{13} \mathrm{C}$ ratios of anchovy as low in the northern region on the Romanian coast, and they attributed this to the fact that the anchovy is less selective and may be more affected by terrestrial inputs. Chouvelon et al. (2014) reported that significantly lower $\delta^{13} \mathrm{C}$ values in anchovy might result from a lower trophic diet or more offshore feeding habits. Another study reported that the $\delta^{13} \mathrm{C}$ difference between anchovies was due to the fact that the Natal anchovy may have lived in the sea longer than Cape anchovy before it was caught (Horton and van der Lingen, 2019).

Our $\delta^{15} \mathrm{~N}$ values ranged from 3.81 to $12.79 \%$ in this study. The average $\delta^{15} \mathrm{~N}$ value was $7.71 \%$. The results (except for the SA station) were found to be more depleted than previous studies. The values at the SA station were in line with the results of Miyachi et al. (2013). Moreover, Anchovy feeds on plankton, such as Calanus genus Copepoda, Cirripedia, and Mollusca larvae (Bingel and Gücü, 2010). The differences in $\delta^{15} \mathrm{~N}$ detected in Anchovy can result from different food sources (Miyachi et al., 2015). The diet of Anchovy is variable, and some anchovies can feed in high trophic positions (Pizarro et al., 2019). It has been stated in many studies that urban development and agricultural activities that cause an increase in denitrification may cause $\delta^{15} \mathrm{~N}$ enrichment (Wada et al., 1987; Altabet et al., 1995; Davias et al., 2014). In a study conducted on the east coast of South Africa, isotopic signs of Natal anchovy and Cape anchovy were compared. According to the results, it has been reported that the higher $\delta^{15} \mathrm{~N}$ value of Cape anchovy than the Natal anchovy is due to the differences in its feeding types and sizes, and may indicate that it feeds at a slightly higher trophic level (Horton and van der Lingen, 2019). In addition to the average $\mathrm{C} / \mathrm{N}$ ratio was 3.82 . This result was similar to the research by Rumolo et al. (Rumolo et al., 2018) in the Central Mediterranean sea.

As a result, $\mathrm{C}$ and $\mathrm{N}$ isotopic signs of European anchovy specimens caught in the Black Sea and the Sea of Marmara were evaluated in this study. It is thought that European anchovy samples caught at İgneada station have more depleted $\delta^{13} \mathrm{C}$ values than other stations, which may be due to the effects of terrestrial inputs in the region. In addition, it is estimated that $\delta^{15} \mathrm{~N}$ is enriched in this station more than others due to feed properties and marine effects of agricultural activities. In addition, it is concluded that it is beneficial to use more stable isotopes in the studies in order to obtain clearer results in this region.

\section{References}

Abend AG, Smith T. 1997. Differences in stable isotope ratios of carbon and nitrogen between long-tinned pilot whales (Globicephala melas) and their primary prey in the western north Atlantic. ICES Journal of Marine Science, 54: 500-503. DOI: $10.1006 / j m s c .1996 .0192$

Altabet MA, Francois R, Murray DW, Prell WL. 1995. Climaterelated variations in denitrification in the Arabian Sea from sediment 15N/14N ratios. Nature, 373: 506-509. DOI: https://doi.org/10.1038/373506a0

Banaru D, Harmelin-Vivien M. 2009. Trophic links and riverine effects on food webs of pelagic fish of the north-western Black Sea. Marine and Freshwater Research, 60: 529-540. https://doi.org/10.1071/MF08005

Bingel F, Gücü AC. 2010. Karadeniz hamsisi ve stok (tespiti) çalişmalari. in: ulusal hamsi çalıştayı.

Bodey TW, Bearhop S, McDonald RA, 2011. Invasions and stable isotope analysis-informing ecology and management. Issg.org 148-151.

Buhan E, Kaymak N, Akin S, Turan H, 2018. Trophic pathways from pelagic and littoral sources supports food web in a trophicpPathways from pelagic and littoral sources supports food web in a eutrophic natural lake (Lake Zinav, Turkey ). Turkish Journal of Fisheries and Aquatic Sciences, 19(2): 99107. DOI: 10.4194/1303-2712-v19_2_02 
Chouvelon T, Chappuis A, Bustamante P, Lefebvre S, Mornet F, Guillou G, Violamer L, Dupuy C, 2014. Trophic ecology of European sardine Sardina pilchardus and European anchovy Engraulis encrasicolus in the Bay of Biscay (north-east Atlantic) inferred from $\delta 13 \mathrm{C}$ and $\delta 15 \mathrm{~N}$ values of fish and identified mesozooplanktonic organisms. Journal of Sea Research, 85: 277-291. https://doi.org/10.1016/ j.seares.2013.05.011.

Como S, van der Velde G, Magni P. 2018. Temporal Variation in the Trophic Levels of Secondary Consumers in a Mediterranean Coastal Lagoon (Cabras Lagoon, Italy). Estuaries and Coasts 41: 218-232. https://doi.org/10.1007/ s12237-017-0265-7

Davias L, Kornis MS, Breitburg DL. 2014. Environmental factors influencing d $13 \mathrm{C}$ and $\mathrm{d} 15 \mathrm{~N}$ in three Chesapeake Bay fishe. ICES Journal of Marine Science, 71: 689-702. DOI: 10.1093/icesjms/fst143

Dempson JB, Braithwaite VA, Doherty D, Power M. 2010. Stable isotope analysis of marine feeding signatures of Atlantic salmon in the North Atlantic. ICES Journal of Marine Science, 67: 52-61. https://doi.org/10.1093/icesjms/fsp227

Duarte CM, Delgado-Huertas A, Anton A, Carrillo-de-Albornoz P, López-Sandoval DC, Agustí S, Almahasheer H, Marbá N, Hendriks IE, Krause-Jensen D, Garcias-Bonet N. 2018. Stable Isotope $(\delta 13 \mathrm{C}, \delta 15 \mathrm{~N}, \delta 18 \mathrm{O}, \delta \mathrm{D})$ Composition and Nutrient Concentration of Red Sea Primary Producers. Frontiers in Marine Science, 5: 298. https://doi.org/ 10.3389/fmars.2018.00298

Einfalt D, Werth M, Schropp D, Kazda M. 2020. Stable carbon isotope analyses offer insights into net carbon degradation of maize silages in anaerobic batch fermentations. Biologia (Bratislava), 75:1043-1054. doi:org/10.2478/s11756-01900403-y

Erdoğan Sağlam N, Sağlam C. 2013. Age, growth and mortality of anchovy Engraulis encrasicolus in the south-eastern region of the Black Sea during the 2010 - 2011 fishing season. Journal of the Marine Biological Association of the United Kingdom, 93: 2247-2255. doi:10.1017/ S0025315413000611

Fry B. 1984. 13C/12C ratios and the trophic importance of algae in Florida Syringodium filiforme seagrass meadows. Marine Biology, 19: 11-19. https://doi.org/10.1007/BF00404980

Fry B. 2006. Stable Isotope Ecology, Conference on Electrical Insulation and Dielectric Phenomena. Springer. Doi:10.1007/ $0-387-33745-8$

Fry B, Sherr E. 1984. $813 \mathrm{C}$ measurements as indicators of carbon flow in marine and freshwater ecosystems. Contributions in Marine Science, 27: 13-47. DOI:10.1007/978-1-4612-3498$2 \_12$

Horton M, van der Lingen CD. 2019. Comparative trophic ecology of Cape anchovy Engraulis encrasicolus and Natal anchovy Stolephorus holodon off South Africa's east coast. African Journal of Marine Science, 41: 269-279. https://doi.org/10.2989/1814232X.2019.1657951

Kideys AE, Gordina AD, Bingel F, Niermann U. 1999. The effect of environmental conditions on the distribution of eggs and larvae of anchovy (Engraulis encrasicolus L.) in the Black Sea. ICES Journal of Marine Science, 56: 58-64. 10.1006/jmsc. 1999.0605

Kloskowski J, Trembaczowski A, Filipiuk M. 2019. Stable isotope tracing of links between marine wintering and freshwater breeding habitats of Red-necked Grebes. Journal of Ornithology, 160: 593-605. https://doi.org/10.1007/ s10336-019-01642-1

Koszelnik P, Tomaszek JA, Gruca-Rokosz R. 2008. Carbon and nitrogen and their elemental and isotopic ratios in the bottom sediment of the Solina-Myczkowce complex of reservoirs. Oceanological and Hydrobiological Studies, 37: 71-78. DOI: 10.2478/v10009-008-0007-z
Lesutiene J, Ložys L, Dainys J, Karosienė J, Pilkaitytė R, Pūtys Ž, Bukaveckas PA, Gasiūnaitė ZR. 2018. Migratory patterns and cyanotoxin concentrations of pikeperch (Sander lucioperca) in the coastal waters of the Baltic Sea. Boreal Environment Research, 23: 315-327.

Letourneur Y, Briand MJ, Graham NAJ. 2017. Coral reef degradation alters the isotopic niche of reef fishes. Marine Biology, 164: 224. https://doi.org/10.1007/s00227-017-3272-0

Melville AJ, Connolly RM. 2003. Spatial analysis of stable isotope data to determine primary sources of nutrition for fish. Oecologia, 136: 499-507. https://doi.org/10.1007/s00442003-1302-8

Miyachi S, Mayahara T, Tsushima K, Sasada K, Kohno E. 2013. Using $\delta 13 \mathrm{C}$ and $\delta 15 \mathrm{~N}$, the study of migrated population for Japanese anchovy, Engraulis japonicus, in Sagami Bay, Japan. Pap Environ Inf Sci, 27: 27-157.

Miyachi S, Mayahara T, Tsushima K, Sasada K, Kohno E, Ogawa NO, Chikaraishi Y, Ohkouchi N. 2015. Approach to determine individual trophic level and the difference in food sources of Japanese anchovy Engraulis japonicus in Sagami Bay, based on compound-specific nitrogen stable isotope analysis of amino acids. Fisheries Science, 81: 1053-1062. DOI: 10.1007/s12562-015-0923-2

Noh J, Yoon SJ, Kim H, Lee C, Kwon BO, Lee Y, Hong S, Kim J, Ryu J, Khim JS. 2019. Anthropogenic influences on benthic food web dynamics by interrupted freshwater discharge in a closed Geum River estuary, Korea. Environment International, 131: 104981. https://doi.org/ 10.1016/j.envint.2019.104981

Owens NJP. 1988. Rapid and total automation of shipboard 15N analysis: examples from the North Sea. Journal of Experimental Marine Biology and Ecology, 122: 163-171. https://doi.org/10.1016/0022-0981(88)90182-7

Pasquaud S, Elie P, Jeantet C, Billy I, Martinez P, Girardin M. 2008. A preliminary investigation of the fish food web in the Gironde estuary, France, using dietary and stable isotope analyses. Estuarine, Coastal and Shelf Science, 78: 267-279, https://doi.org/10.1016/j.ecss.2007.12.014.

Peterson BJ. 1999. Stable isotopes as tracers of organic matter input and transfer in benthic food webs: A review. Acta Oecologica, 20: 479-487. DOI:10.1016/S1146-609X(99) 00120-4

Peterson BJ, Fry B. 1987. Stable Isotopes in Ecosystem Studies. Annual Review of Ecology, Evolution, and Systematics, 18: 293-320.

Pinnegar JK, Polunin NVC. 1999. Differential fractionation of $\delta 13 \mathrm{C}$ and $\delta 15 \mathrm{~N}$ among fish tissues: Implications for the study of trophic interactions. Functional Ecology, 13: 225-231. https://doi.org/10.1046/j.1365-2435.1999.00301.x

Pizarro J, Docmac F, Harrod C. 2019. Clarifying a trophic black box: Stable isotope analysis reveals unexpected dietary variation in the Peruvian anchovy Engraulis ringens. PeerJ, 1-22. https://doi.org/10.7717/peerj.6968

Polat H, Ergün H. 2008. Karadeniz'in pelajik baliklari. Yunus, 8(1): $1-5$.

Post DM. 2002. Using stable isotopes to estimate trophic position: models, methods, and assumptions. Ecology, 83: 703718.https://doi.org/10.1890/0012-9658(2002)083[0703: USITET]2.0.CO;2

Post DM, Layman CA, Arrington DA, Takimoto G, Quattrochi J, Montana CG. 2007. Getting to the fat of the matter: Models, methods and assumptions for dealing with lipids in stable isotope analyses. Oecologia, 152: 179-189. https://doi.org/10.1007/s00442-006-0630-x

Prodanov K, Mikhailov K, Daskalov G, Maxim C, Chashchin A, Arkhipov A, Shlyakhov V, Ozdamar E. 1997. Environmental management of fish resources in 6 the Black Sea and their rational exploitation. GFCM Studies Review, 68: 178. 
Rumolo P, Bonanno A, Barra M, Fanelli E, Calabrò M, Genovese S, Ferreri R, Mazzola S, Basilone G. 2016. Spatial variations in feeding habits and trophic levels of two small pelagic fish species in the central Mediterranean Sea. Marine Environmental Research, 115: 65-77. DOI: 10.1016/j.marenvres.2016.02.004

Rumolo P, Fanelli E, Barra M, Basilone G, Genovese S, Gherardi S, Ferreri R, Gargano A, Mazzola S, Bonanno A. 2018. Trophic relationships between anchovy (Engraulis encrasicolus) and zooplankton in the Strait of Sicily ( Central Mediterranean sea): a stable isotope approach. Hydrobiologia, 821: 41-56. DOI: 10.1007/s10750-017-3334-9

Samsun O, Samsun N, Karamollaoğlu AC. 2004. Age, growth, and mortality rates of the European anchovy (Engraulis encrasicolus L. 1758) off the Turkish Black Sea coast. Turkish Journal of Veterinary and Animal Sciences, 28: $901-$ 910.

Şahin C, Gözler AM, Hacımurtazaoglu N, Kongur N. 2006. 20042005 Av Sezonunda Doğu Karadeniz'deki Hamsi (Engraulis encrasicolus L., 1758) Populasyonunun Yapis1.E.U. Journal of Fisheries and Aquatic Science, 23: 497-503.
TUIK 2019. Turkish Statistical Institute Fishery Statistics.

Wada E, Minagawa M, Mizutani H, Tsuji T, Imaizumi R, Karasawa K. 1987. Biogeochemical studies on the transport of organic matter along the Otsuchi River watershed, Japan. Estuarine, Coastal and Shelf Science, 25: 321-336. https://doi.org/10.1016/0272-7714(87)90075-8

Wan R, Wu Y, Huang L, Zhang J, Gao L, Wang N. 2010. Fatty acids and stable isotopes of a marine ecosystem: Study on the Japanese anchovy (Engraulis japonicus) food web in the Yellow Sea. Deep-Sea Research Part II: Topical Studies in Oceanography, 57: 1047-1057. https://doi.org/10.1016/ j.dsr2.2010.02.006

Wang L, Tang W, Dong W. 2015. The signatures of stable isotopes $\delta 15 \mathrm{~N}$ and $\delta 13 \mathrm{C}$ in anadromous and nonanadromous Coilia nasus living in the Yangtze River, and the adjacent sea waters. Journal of Ocean University of China, 14: 1053-1058. https://doi.org/10.1007/s11802-015-2611-3 